\title{
THE STUDY OF EFFECTS OF “CHONDROLIFE” COMBINED CREAM-GEL IN THE SPONTANEOUS PAIN SENSITIVITY EXPERIMENT
}

\author{
S.K.Shebeko, S.M.Zimin
}

National University of Pharmacy

Key words: osteoarthritis; glucosamine; chondroitine; local therapy; pain; analgesimetry

\begin{abstract}
The leading areas of pathogenetic treatment of osteoarthritis include: modulation of inflammation, regulation of metabolism of chondrocytes and stimulation of the cartilage synthesis. Relief of pain is another no less important aspect of the therapy. Today, along with the regular use of drugs the treatment of the articular syndrome in osteoarthritis focuses on the local therapy, including the use of ointments and gels. The aim of this work was to study the analgesic action of the original cream-gel under the conditional name "Chondrolife" containing glucosamine hydrochloride, chondroitin sulphate, camphor and menthol. The antinociceptive effect of "Chondrolife" cream-gel compared to the reference drugs "Chondroxide ${ }^{\circledR ”}$ gel and "Diclac gel ${ }^{\circledR}$ " was studied when externally applied on the model of carrageenan-induced acute gonarthritis in rats by the impact to the severity of spontaneous pain using an Incapacitance Tester MkV ("Linton Instrumentation", Great Britain). "Chondrolife" cream-gel has shown a significantly better antinociceptive effect compared to the reference drug "Chondroxide ${ }^{\circledR ”}$ gel and is not inferior "Diclac gel ${ }^{\circledR ”}$ by the antinociceptive activity on the $6^{\text {th }}$ hour (in 1 hour after applying the drugs under study). Although on the seventh hour the activity (in 2 hours after applying the drugs under study) of "Chondrolife" cream-gel gradually reduces and is slightly inferior the activity of "Diclac gel ${ }^{\circledR}$ ", it is likely higher than that of "Chondroxide ${ }^{\circledR ”}$ gel. It allows continuing our study of "Chondrolife" combined cream-gel as a chondroprotective analgesic agent for local application.
\end{abstract}

ccording to various studies the frequency of pain in the knee joints in the presence of radiographic osteoarhthritis ranged from 40 to $80 \%$, and increase in the frequency of pain was observed in people aged over 50 years $[1,13]$.

According to the current data the main directions of pathogenetic treatment of osteoarthritis (OA) include: modulation of inflammation, regulation of metabolism of chondrocytes and stimulation of the cartilage synthesis [15]. Relief of pain is another no less important aspect of therapy since the overwhelming number of OA patients suffers from chronic pain [5].

Experts of the European Antirheumatic League (EULAR) and the American Association of Rheumatology (OARSI) have developed recommendations for treating $\mathrm{OA}$, which include non-pharmacological, pharmacological and surgical treatments [8]. There are 3 main principles of OA treatment: pain relief, removal of inflammation, further delayed cartilage degeneration [11].

All drug treatments of $\mathrm{OA}$ are divided into 3 main groups: rapid acting symptom-modifying drugs (simple analgesics, nonsteroidal anti-inflammatory drugs, opioid analgesics, intraarticular injections of glucocorticoids, transdermal drug forms); Symptomatic Slow Acting Drugs for Osteoarthritis (SYSADOA) (chondroitine sulphate, glucosamine sulphate, piascledine, drugs of hyaluronic acid) $[8,11]$.

Therapy of OA is a long, almost life-long process, and a special attention should be paid to the effective and safe use of drugs [9]. SYSADOA combine all the necessary qualities for long-term rehabilitation. Monotherapy with SYSADOA is recommended in the non-acute condition. It is recommended to combine SYSADOA with NSAIDs when the pain syndrome exacerbates since the analgesic action of the last develops much faster. The combined use can reduce the dose of NSAIDs, thus preventing a number of undesirable side effects $[10,12]$.

Today, along with the regular use of drugs the treatment of the articular syndrome in osteoarthritis focuses on the local therapy, including the use of ointments and gels [14]. The preference should be given to the local treatment over the systemic therapy, especially in case of a mild or moderate pain, and when only a few joints are involved [13].

Inclusion of the local therapy in the complex of therapeutic measures in OA has a number of advantages: a purposeful effect on the main inflammatory focus (the most affected joints) and reduction of the need for prescribed drugs with a negative impact on the condition of the gastrointestinal tract, cardiovascular and nervous systems, etc. The latest OARSI recommendations for OA therapy regulate the use of different groups of drugs, including local NSAIDs [15].

The aim of this work was to study the analgesic action of the original cream-gel under the conditional name "Chondrolife" with 
the following composition: glucosamine hydrochloride $-5.0 \mathrm{~g}$, chondroitin sulphate $-5.0 \mathrm{~g}$, camphor $3.2 \mathrm{~g}$, menthol $-0.5 \mathrm{~g}$, excipients up to 100 g. "Chondroxide ${ }^{\circledR ”}$ gel (manufactured by NizhpharmSTADA, Russia) containing $5 \%$ of chondroitine sulphate and "Diclac gel ${ }^{\circledR ”}$ (manufactured by Sandoz AG, Slovenia) containing 5\% of diclofenac sodium were chosen as reference drugs.

\section{Materials and Methods}

The antinociceptive effect of "Chondrolife" cream-gel compared to the reference drugs "Chondroxi$\mathrm{de}^{\circledR}$ " gel and “Diclac gel ${ }^{\circledR ”}$ was studied when externally applied on the model of carrageenan-induced acute gonarthritis in rats by the impact to the severity of spontaneous pain using an Incapacitance Tester MkV ("Linton Instrumentation", Great Britain) [2].

The study used 40 white nonlinear rats of both sexes weighing 170-180 g, they were kept in the vivarium of the Central Research Laboratory of the NUPh on a standard food and water diet in accordance with the current regulations [4]. The experiment was performed in full compliance with the requirements of the Commission on Bioethics of the NUPh and the European Convention for the Protection of Vertebrate Animals used for Experimental and Other Scientific Purposes [7].

Animals were divided into four experimental groups in the following way: Group 1 - animals with experimental gonarthritis without treatment (control pathology); Group 2 - animals receiving "Chondrolife" cream-gel in the dose of $50 \mathrm{mg}$ per an animal; Group 3 animals receiving "Chondroxide" gel in the similar dose of $50 \mathrm{mg}$; Group 4 - animals receiving "Diclac gel ${ }^{\circledR "}$ in the same dose of $50 \mathrm{mg}$.

To remove hair from the skin of the knee joint and induce inflammation of the joint the rats were subjected to anesthesia using intraperitoneal injection of phe- nobarbital in the dose of $40 \mathrm{mg} / \mathrm{kg}$. After the onset of anesthesia the areas of both knee joints were depilated using a depilatory cream. Depilation has advantages over shaving as it does not damage the skin, which, in its turn, is important when using medications of the local action, especially those that contain NSAIDs.

To induce acute gonarthrosis $25 \mu \mathrm{l}$ of $2 \%$ solution $\lambda$-carrageenan (Sigma, USA) was injected in the right knee. In 5 hours after inducing the disease the samples of the drugs under study were once applied to all animals on both hind limbs as skin applications in the doses of $50 \mathrm{mg}$ per an animal with fully rubbing them to prevent selflick of the drug by animals. Within 5 days before the experiment all animals were kept in the holding chamber of the apparatus to reduce the signs of stress and improve the measurement accuracy during the experiment.

Development of spontaneous pain in animals with carrageenaninduced acute gonarthritis and distribution of the load on the hind limbs were studied using an Incapacitance Tester MkV ("Linton Instrumentation", Great Britain). Measurement of the intensity of the spontaneous pain reaction was performed in 1 and 2 hours after application of the gels under study. For this purpose, each animal was placed into the fixing chamber of the tester and left there for $5 \mathrm{~min}$ to acclimatize until the animal adapted and took a comfortable position. The rat's hind limbs should be at plates of the loading device separately, and fore limbs on the sloping front wall of the chamber. Thus, the entire weight of the animal was redistributed through the hind limbs on the weight sensors of the tester. Redistribution of the body weight was measured three times with an interval of 5 seconds, and the average of the body weight falling on the right and left limb separately was recorded. This test allowed assessing the severity of pain in the in- jured paw by the nature of distribution of the weight on the hind limbs at a fixed position of the animal in the chamber. Data on distribution of the weight on the right and left limb (g) were calculated as a percentage of the total weight of animals using the formula:

$$
\mathrm{ID}=\frac{\mathrm{MRL}}{\mathrm{MRL}+\mathrm{MLL}} \times 100,
$$

where ID - is the index of disability (\%);

MRL - is the body weight of the animal distributed to the right (affected) limb;

MLL - is the weight of the animal distributed to the left (healthy) limb.

The analgesic activity (AA) was calculated according to the ability of the drugs under study to decrease of the spontaneous pain in the experimental animals. It was determined by increase of ID in animals of the experimental groups compared to the control pathology group. The analgesic activity was calculated according to the following formula:

$$
\mathrm{AA}=\frac{\mathrm{ID}-\mathrm{ID}_{\mathrm{cg}}}{\mathrm{ID}_{\mathrm{cg}}} \times 100 \%,
$$

where AA - is the analgesic activity;

$\mathrm{ID}_{\mathrm{cg}-}$ is the index of disability in the experimental group of animals with the control pathology;

ID - is the index of disability in the experimental group of animals treated with the gels under study.

Statistic processing of the results obtained was performed by the methods of variation statistics using Student t-test and non-parametric methods for analysis (MannWhitney U Test) with STATISTICA 7.0 and MS Excel 2007 PC software.

\section{Results and Discussion}

In the intact animals distribution of the weight on the right and left limbs was in the range of $50: 50 \%$ of the body weight, and the pain that spontaneously developed in animals with acute carrageenan-induced gonarthritis was 
Table

\section{The effect of "Chondrolife" cream-gel on the spontaneous pain reaction on the model of carrageenan-induced acute gonarthritis in rats}

\begin{tabular}{|l|c|c|c|}
\hline $\begin{array}{c}\text { Conditions of the } \\
\text { experiment }\end{array}$ & $\mathrm{n}$ & $\begin{array}{c}\text { Index of disability, } \\
\text { ID (\%) }\end{array}$ & $\begin{array}{c}\text { Analgesic activity, } \\
\text { AA (\%) }\end{array}$ \\
\hline \multicolumn{5}{|c|}{ On the $6^{\text {th }}$ hour of the experiment } \\
(in 1 hour after applying the drugs under study)
\end{tabular}

Notes:

1) * - deviation is significant compared to control, $p<0.05$;

2) ${ }^{* *}$ - deviation is significant compared to the reference drug «Chondroxide ${ }^{\oplus}$ » gel, $\mathrm{p}<0.05$;

3) *** - deviation is significant compared to the reference drug "Diclac gel ${ }^{\oplus ",} p<0.05$;

4) $n-$ is the number of animals in the group.

accompanied with decrease in the load on the affected limb in animals of all experimental groups with more active use of the intact limb [15].

The results of studying the analgesic activity of the drugs under research are presented in Table.

Animals in the control pathology group (with carrageenan-induced gonarthritis and without treatment) kept $73.9 \%$ of their own weight by the intact limb in 6 hour after modelling of pathology. At the same time the animals received "Chondrolife" cream-gel and "Diclac gel ${ }^{\circledR ”}$ distributed their weight $(53.4 \pm 2.0$ and $55.4 \pm 2.4$, respectively) almost symmetrically, while in the "Chondroxide ${ }^{\circledR ”}$ group $68.7 \%$ of the weight were on the intact paw.

Later, in 2 hours after treatment with the drugs under study the weight distribution to the intact and the affected limb of the animals of the control pathology group was $70.7 \%: 29.3 \%$. In the second experimental group of animals treated with "Chondrolife" cream-gel the antinociceptive effect decreased slightly, and the weight distribution was 60.4 : 39.6\%; in the third group receiving "Chondroxide $^{\circledR \text { " }}$ gel the weight distribution was practically unchanged, and it was $66.4: 33.6$, while the weight distribution in the fourth group of animals treated with "Diclac gel ${ }^{\circledR ”}$ remained virtually the same as the weight distribution in healthy rats - $53.6: 46.4$.

The analgesic activity of "Chondrolife" cream-gel was $27.74 \pm 0.53 \%$ on the $6^{\text {th }}$ hour (in 1 hour after applying the drugs under study), and it was statistically higher compared to the reference drugs "Chondroxide ${ }^{\circledR ”}$ gel $(7.04 \pm 0.36 \%)$ and "Diclac gel ${ }^{\circledR ”}(25.04 \pm 0.63 \%)$. On the $2^{\text {nd }}$ hour of the experiment the highest AA had "Diclac gel ${ }^{\circledR "}$ $(24.19 \pm 0.65 \%)$, this activity had the same level with the $1^{\text {st }}$ hour marker. The analgesic activity of "Chondrolife" gel was $14.57 \pm 0.47 \%$, which was lower than that on the $1^{\text {st }}$ hour. The analgesic activity of “Chondroxide ${ }^{\circledR}$ " gel was $6.08 \pm 0.71 \%$ on the $2^{\text {nd }}$ hour, and it was statistically lower than that in other drugs studied.
The rapid and strong analgesic effect is typical for "Chondrolife" cream gel due to the presence of menthol and camphor with their revulsive and cooling action in its composition. However, it is known that the effect of these drugs is not long, and our experiment confirms it. On the other hand, the analgesic activity of "Diclac gel ${ }^{\circledR ”}$ is due to diclofenac sodium in it. At the same time the analgesic effect of glucosamine and chondroitin develops more slowly and acquires its maximum due to inhibition of inflammation and positive morphological and structural changes in the joint cartilage [6]. Thus, this combined creamgel possesses the properties of symptom-modifying drugs (due to inhibition of pain) and diseasemodifying properties (due to a marked effect of "Chondrolife" cream-gel on the morphological and structural characteristics of the articular cartilage) as shown in the previous experiments [3].

CONCLUSIONS

1. "Chondrolife" cream-gel has shown a significant antinociceptive effect in acute pain on the model of carrageenan-induced acute gonarthritis in rats.

2 . The antinociceptive activity of "Chondrolife" cream-gel is statistically higher than that of the reference on the $6^{\text {th }}$ hour of the experiment (in 1 hour after applying the drugs under study).

3. The antinociceptive activity of "Chondrolife" cream-gel is statistically higher than that of the reference drug "Chondroxide ${ }^{\circledR}$ " on the $7^{\text {th }}$ hour of the experiment (in 2 hours after applying the drugs under study), but is slightly lower than that of the reference drug "Diclac gel ${ }^{\circledR ”}$.

4. The analgesic activity of "Chondrolife" cream-gel in acute pain on the model of carrageenaninduced acute gonarthritis in rats is due to the presence of menthol and camphor in its composition.

5. The data provide the basis for further preclinical study of "Chondrolife" combined cream-gel as a chondroprotective and analgesics drug of topical application. 


\section{REFERENCES}

1. Балабанова Р.М., Эрдес Ш.Ф. // Научно-практ. ревматол. - 2012. - №3. - С. 10-12.

2. Доклинические исследования лекарственных средств: Метод. рекоменд. / Под ред. А.В.Стефанова. - К.: Авиценна, 2002. - 528 с.

3. Зупанец И.А., Зимин С.M. // European Applied Sci. - 2013. - Vol. 10 (1). - P. 58-61.

4. Кожем'якін Ю.М., Хромов О.С., Філоненко М.А., Сайфетдінова Г.А. Науково-практичні рекомендації з утримання лабораторних тварин та роботи з ними. - К.: Державний фармакологічний центр МОЗ України, 2002. - 155 c.

5. Bruyère O., Cooper C., Pelletier J.P. et al. //Semin. Arthritis Rheumatol. - 2014. - Vol. 44, №3. - P. 253-263.

6. EULAR Textbook on Rheumatic Diseases / Ed. Johannes W.J.Bijlsma // Osteoarthritis Treatment. - 2012. - P. 749-768.

7. European convention for the protection of vertebrate animals used for experimental and other scientific purpose: Council of Europe. - Strasbourg, 1986. - 52 p.

8. Felson D.T., Niu J., Yang T. et al. // Osteoarthritis and Cartilage. - 2013. - Vol. 21, №6. - P. 789-795.

9. Harirforoosh S., Asghar W., Jamali F. // J. Pharm. Sci. - 2013. - Vol. 16, №5. - P. 821-847.

10. Hrnack S.A., Barber F.A. // Phys. Sportsmed. - 2015. - Vol. 42, №3. - P. 63-70.

11. McAlindon T.E., Bannuru R.R., Sullivan M.C. et al. // Osteoarthritis and Cartilage. - 2014. - Vol. 22, №3. - P. 363-388.

12. Peniston J.H., Gold M.S., Alwine L.K. // Phys. Sportsmed. - 2011. - Vol. 39, №3. - P. 31-38.

13. Pulsatelli L., Addimanda O., Brusi V. et al. // Ther. Adv. Chronic Dis. - 2013. - Vol. 10, №1. - P. 23-43.

14. Runhaar J., van Middelkoop M., Reijman M. et al. // Am. J. Med. - 2015. - Vol. 128, №8. - P. 888-895.

15. Zhang W., Doherty M., Peat G. et al. // Ann. Rheum. Dis. - 2010. - Vol. 69, №3. - P. 483-489.

\section{ЕКСПЕРИМЕНТАЛЬНЕ ВИВЧЕННЯ ВПЛИВУ КОМБІНОВАНОГО КРЕМ-ГЕЛЮ «ХОНДРОЛАЙФ» НА СПОНТАННУ БОЛЬОВУ ЧУТЛИВІСТЬ \\ С.К.Шебеко, С.М.Зімін}

Національний фармацевтичний університет

Ключові слова: остеоартроз; глюкозамін; хондроїтин; локальна терапія; біль; аналгезіметрія

Провідними напрямками патогенетичного лікування остеоартрозу є: модуляція запалення, регуляція метаболізму хондроцитів і стимуляція синтезу хряща. Зменшення больового синдрому - ще один не менш важливий аспект терапії. На сьогоднішній день поряд із системним застосуванням препаратів у терапії суглобового синдрому при остеоартрозі велика увага приділяється локальній (місцевій) терапії, в тому числі із застосуванням мазей і гелів. Метою даного дослідження стало вивчення аналгетичної дії оригінального крем-гелю під умовною назвою «Хондролайф» із вмістом глюкозаміну гідрохлориду, хондроїтину сульфату, камфори та ментолу.

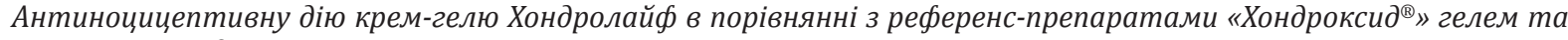
«Диклак гелем ${ }^{\circledR}$ » досліджували при нашкірному нанесенні на моделі карагенін-індукованого гострого гонартриту у шурів за впливом на виразність спонтанного больового синдрому за допомогою «тестера інвалідності» - Incapacitance Tester MkV («Linton Instrumentation», Великобританія). Крем-гель «Хондролайф» показав значно кращий антиноцицептивний ефект у порівнянні з контрольним препаратом «Хондроксид ${ }^{\circledR}$ та не поступається антиноцицептивній активності «Диклак гелю ${ }^{\rrbracket_{1}}$ на шостій годині експерименту (через 1 год після нанесення на шкіру), і хоча на сьомій годині (на другій годині після нанесення) активність після нанесення крем-гелю «Хондролайф» поступово знижується та дещо поступається активності «Диклак гелю®», вона вірогідно вища, ніж у гелю «Хондрокси ${ }^{\circledR}$ », що дає підставу для продовження вивчення комбінованого крем-гелю «Хондролайб»у якості хондропротекторного та аналгетичного засобу для місцевого застосування.

\section{ЭКСПЕРИМЕНТАЛЬНОЕ ИЗУЧЕНИЕ ВЛИЯНИЯ КОМБИНИРОВАННОГО КРЕМ-ГЕЛЯ «ХОНДРОЛАЙФ» НА СПОНТАННУЮ БОЛЕВУЮ ЧУВСТВИТЕЛЬНОСТЬ \\ С.К.Шебеко, С.М.Зимин}

Национальный фармацевтический университет

Ключевые слова: остеоартроз; глюкозамин; хондроитин; местное лечение; боль; анальгезиметрия

Ведущими направлениями патогенетического лечения остеоартроза являются: модуляция воспаления, регуляция метаболизма хондроцитов и стимуляция синтеза хряща. Уменьшение болевого синдрома - еще один не менее важный аспект терапии. На сегодняшний, день наряду с системным применением препаратов, в терапии суставного синдрома при остеоартрозе большое внимание уделяется локальной (местной) терапии, в том числе с применением мазей и гелей. Целью данного исследования стало изучение анальгетического действия оригинального крем-геля под условным названием «Хондролайф» с содержанием глкозамина гидрохлорида, хондроитина сульфата, камфоры и ментола. Лечебное антиноцицептивное действие крем-геля «Хондролайф» 
по сравнению с референс-препаратами «Хондроксид ${ }^{\circledR} 》$ гелем и «Диклак гелем ${ }^{\circledR} 》$ исследовали при наружном нанесении на модели карагенин-индущированного острого гонартрита у крыс по влиянию на выраженность спонтанного болевого синдрома с помощью «тестера инвалидности» - Incapacitance Tester MkV («Linton Instrumentation», Великобританія). Крем-гель «Хондролайф» показал значительно лучшую антиноцицептивную активность по сравнению с контрольным препаратом «Хондрокси ${ }^{\circledR}$ » и не уступает антиноцицептивной активности "Диклак геля ${ }^{{ }_{\Perp}}$ на шестом часу эксперимента (через 1 час после нанесения исследуемых препаратов), и, хотя на седьмом (через 2 часа после нанесения исследуемых препаратов) часу активность крем-геля «Хондролайф» постепенно снижается и несколько уступает активности "Диклак геля ${ }^{\circledR}$ », она достоверно выше, чем у геля “Хондрокси ${ }^{\circledR} 》$, что дает основание для продолжения изучения комбинированного крем-геля «Хондролайб» в качестве хондропротекторного и анальгетического средства местного применения.

Address for correspondence:

Received in 11.05.2016

27, Pushkinska str., Kharkiv, 61057, Ukraine.

Tel. (57) 706-30-72. E-mail: clinpharm@nuph.edu.ua.

National University of Pharmacy 